\title{
Stavovi građana centralnog dela Srbije prema uticaju doseljenika na tradiciju i kulturu njihove lokalne zajednice
}

DOI: $10.11567 /$ met.31.2.2 UDK: 314.742:316.7](497.11) ]"2013"

Izvorni znanstveni rad

Primljeno: 16. 04. 2015. Prihvaćeno: 29. 09. 2015.

\author{
Milica Vesković Anđelković
}

Filozofski fakultet u Beogradu, Beograd

milica.ves@gmail.com

\section{Mirjana Bobić}

Filozofski fakultet u Beogradu, Beograd

matildab@eunet.rs

\section{REZIME}

Od kraja prošlog veka do danas u Srbiji se povećava broj imigranata koji pristižu sa više strana. Prvenstveno, reč je o prisilno raseljenom stanovništvu sa teritorije bivše Jugoslavije, koji su se i više od dve decenije nakon završenih sukoba i relativne normalizacije odnosa, još uvek zadržali na srpskoj teritoriji. Dalje, izuzetno je povećan i broj tražilaca azila kao i drugih iregularnih migranata. S obzirom da demografske projekcije i iskustva bivših socijalističkih zemalja ukazuju da je u narednih nekoliko decenija realno očekivati migracionu tranziciju u smeru imigracije, a posebno sa formalnim članstvom u EU, čini se da je potrebna veća vizibilizacija ovog fenomena kako bi se išlo u susret ovim društvenim promenama. Cilj ovog rada jeste da uz osvrt na geopolitički položaj Srbije i dugoročne prognoze u pogledu imigracije, pruži pregled stavova građana Srbije prema doseljenicima, naročito u odnosu na njihov uticaj na lokalnu kulturu, običaje i svakodnevicu. Podaci koji su izneseni i analizirani prikupljeni su anketnim istraživanjem koje je Institut za sociološka istraživanja Filozofskog fakulteta u Beogradu, obavio tokom 2013. godine. U radu se pored stavova domicilnog stanovništva o uticaju doseljenika, analizira i njihovo mišljenje o uticaju stranaca na kulturu i svakodnevni život u njihovim lokalnim sredinama.

KLJUČNE REČI: Srbija, migracija, doseljenici, kultura, tradicija

\section{UVOD}

Od kraja prošlog veka do danas u Srbiji se iz godine u godinu povećava broj imigranata koji pristižu sa više strana (Bobić, 2013b). Na prvom mestu, reč je o 617.728 izbeglih i drugih ratom ugroženih lica, koliko ih je 
registrovano 1996., pretežno sa područja Hrvatske i Bosne i Hercegovine. Izbeglice su u najvećem broju u Srbiju dolazile krajem 20. veka kada su se vodili ratovi na teritoriji nekadašnje Jugoslavije. Broj doseljenog stanovništva u Srbiji je još jednom dramatično povećan dolaskom 197.500 interno raseljenih lica sa Kosova i Metohije, nakon sukoba sa većinskim albanskim stanovništvom, čiji vrhunac predstavlja bombardovanje 1999. godine od strane NATO-a (Bobić, 2010). I nakon decenije i po, iako je broj izbeglica višestruko smanjen (u 2013. 66.000, Bobić i Babović, 2013), činjenica je da i dalje većina ovih prisilnih imigranata ostaje na teritoriji gde su se naselili, dok je vrlo mali udeo onih koji su se vratili na napuštena ognjišta. Štaviše broj raseljenih lica sa Kosova i iz Metohije ne samo da se nije smanjio već se konstantno povećava (u 2013. oko 215.000, Bobić i Babović, 2013), usled još uvek nestabilne političke situacije. Poslednjih godina enormno je povećan i broj tražilaca azila kao i drugih iregularnih migranata, uključujući i žrtve krijumčarenja žena i dece (Bobić, 2013b). Kada govorimo o imigrantima na teritoriji Srbije, treba imati na umu da prednjače Kinezi (Stavovi građana prema izbeglicama,..., 2012), čiji je boravak evidentan u svakodnevnom životu, u susedstvima i lokalnim zajednicama urbanih područja širom Srbije. Na kraju, treba pomenuti i povratnike koji, po osnovu Sporazuma o readmisiji, pristižu u sve većem broju (Bobić i Babović, 2013). ${ }^{1}$ Ovde se ne misli samo na lica koja su ilegalno prešla granicu ili su emigrirala tokom ratnih sukoba na Balkanu, već i na lica koja su emigrirala tokom šezdesetih i sedamdesetih godina prošlog veka u cilju pronalaska bolje plaćenog posla.

Razne gore pobrojane kategorije doseljenika, čiji dolazak, osim što utiče na demografsku sliku zemlje i osnov za demografske projekcije, utiče i na svakodnevni život i vrednosni sistem celokupnog srpskog društva. Ipak, njihov uticaj se najviše primećuje na promenama nastalim u okviru lokalnih kultura zajednica sa kojima su imigranti u svakodnevnom kontaktu. Tema ovog rada jeste upravo prikaz uticaja migranata na lokalnu kulturu, posmatrano iz perspektive pojedinaca. U tu svrhu biće korišćeni podaci anketnog istraživanja koje je Institut za sociološka istraživanja Filozofskog fakulteta u Beogradu obavio u proleće 2013. godine u okviru projekta „Karakteristike teritorijalnog kapitala u Srbiji“. Pored toga što će prikupljeni podaci biti korišćeni za analizu ocene uticaja imigranata na lokalnu kulturu, radi uporedne analize biće izneti i podaci o stavovima ispitanika o njihovom uticaju

Prema podacima popisa 1991. u Srbiju se vratilo ukupno 62.843 lica, da bi se u popisu 2011. registrovalo čak njih 234.932 (Станковић, 2014: 23). Međutim, iako se broj povratnika uvećao skoro četiri puta, njihov broj još uvek nije na zavidnom nivou, što se uglavnom može objasniti socijalnim i ekonomskim standardom koji je ispod standarda u zemljama destinacije. 
na druge aspekte društvenog života zajednice, prvenstveno ekonomiju. Cilj je da se utvrdi značaj koji ispitanici pridaju kulturnim promenama u odnosu na ostale promene nastale kao posledica doseljavanja stanovništva na teritorijama ispitivanih opština.

Pre analize dobijenih podataka biće napravljen kratak osvrt na najbitnije procese i događaje koji su uticali na društveni život etničkih zajednica širom sveta. Posebno će se napraviti osvrt na dešavanja koja su podstakla masovnije kretanje stanovništva na Balkanu što za posledicu ima njihovo intenzivnije mešanje i višestruki međusobni uticaj. Nakon razjašnjenog kontekstualnog okvira rada, u trećem delu će biti prikazani hipotetički okvir i korišćena metodologija. U četvrtom delu rada, biće analiziran uticaj imigranata doseljenih sa teritorija bivše Jugoslavije, dok će tema petog poglavlja biti uticaj kineskih doseljenika, kao kulturno „dalekog“ naroda, na život lokalne zajednice. U radu se ne nalazi analiza uticaja povratnika i azilanata iz razloga što u upitniku nije bilo pitanja posebno usmerenih na ove grupe. Uz to, na teritorijama gde je sprovedeno istraživanje broj azilanata je zanemarljiv, a povratnika nepoznat. Na kraju će biti sumirani osnovni rezultati analize.

\section{KONTEKSTUALNI OKVIR ISTRAŽIVANJA}

Poslednje decenije prošlog veka i početak novog obeležene su događajima i procesima koji su višestruko uticali na socijalnu i kulturnu transformaciju nacionalnih zajednica širom sveta, pri čemu se ona najviše osetila na teritorijama država koje se nalaze na istočnom delu Starog kontinenta. Prvo, proces globalizacije, koji pored političkih i ekonomskih obuhvata i društveno kulturne promene čineći ih interregionalnim pa čak i interkontinentalnim, utiče na intenzifikaciju stepena interakcije i međusobne povezanosti između različitih etničkih zajednica (Held et al., 1999). Ovaj nezaustavljivi proces, koji je počeo da se zahuktava sedamdesetih godina XX veka (Geiger Zeman i Zeman, 2010: 114), ne samo da utiče na transformaciju načina ekonomskog života unutar država, već se njegov uticaj prepoznaje u svakodnevnom životu građana, kao i u procesu oblikovanja kultura etničkih zajednica i stepenu očuvanja njihove tradicije - običaja i vrednosti. Lokalne kulture usled procesa globalizacije dolaze u interakciju sa kulturnim tekovinama pristiglim i sa Zapada i sa Istoka, što dalje usmerava proces njihovog razvoja odnosno preobražaja. Pritom, ipak treba imati u vidu da i u ovakvim uslovima svakodnevnog mešanja kulturno različitih naroda, 
nacionalne kulture, ujedno i zadržavaju sopstveni identitet, koji ih čini posebnim.

Proces globalizacije, međutim, nije jedini koji je uticao na sveukupnu transformaciju života društvenih grupa na našim prostorima. Kraj Hladnog rata i rušenje Berlinskog zida 1989. pored toga što su ubrzali već započetu transformaciju u kapitalizam u državama Istočnog bloka, simbolički predstavljaju nestanak političkih barijera za emigraciju stanovništva iz bivših socijalističkih država. ${ }^{2}$ Svesne realne mogućnosti još masovnijeg priliva stanovništva i posledica tog procesa na celokupni društveni sistem, države članice nekadašnje Evropske ekonomske zajednice (preteče današnje Evropske unije), počele su ubrzano da uspostavljaju oštru kontrolu migracionih tokova. Uvođenje barijera masovnoj imigraciji sa teritorija „država u tranziciji”, nije, međutim, zaustavilo iseljavanje ovog stanovništva. Suprotno očekivanom, donošenje rigoroznijih imigracionih politika uzrokovalo je pojavu novih tokova i oblika pokretljivosti što je dalje uticalo na modifikaciju evropskih migratornih obrazaca (Bonifazi, 2004). Podstaknuti teškim uslovima života koji su dodatno pogoršani krizom usled nastupajuće socioekonomske transformacije u tržišnu privredu, migranti iz nekadašnjih socijalističkih država kretali su se uglavnom ka tradicionalnim imigrantskim zemljama (SAD i članice Evropske Unije), koje su, iz njihove perspektive, predstavljale „obećane zemlje”, što je prvenstveno podrazumevalo bolji materijalni standard.

Porast broja migranata u ovom periodu imao je višestrukog efekta i na društva njihovih matičnih država i na društva destinacije. Dugoročno gledano, devizne doznake koje imigranti šalju rodbini i njihove investicije u vidu materijalnih sredstava u državu porekla postepeno ublažavaju disparitet među državama u pogledu ekonomskog standarda i privrednog razvoja (Vertovec, 2004). Započinjući život na drugim teritorijama, migranti se postepeno uklapaju u tamošnje društvo, usvajaju navike, običaje, vrednosti i druge kulturne karakteristike koje su zatekli, ali im i priključuju kulturne karakteristike društva porekla koje su usvojili u pređašnjem periodu života. Tako, migracije utiču na modifikaciju celokupnog načina života domicilnog

Treba, međutim, istaći da migracioni tokovi stanovništva ne postaju znatno masovniji završetkom Hladnog rata, već da samo poprimaju nove oblike. Veliki broj imigranata napustio je bivše socijalističke države odmah nakon Drugog svetskog rata iz političkih razloga (Filipović, 2012), dok šezdesetih godina prošlog veka, na samom početku perioda postindustrijskog kapitalizma (Bobić, 2013b: 102) sve više raste broj migranata koji odlaze na privremeni rad $\mathrm{u}$ inostranstvo, uglavnom Evropu i SAD. Ovaj period koji započinje sredinom XX veka, neki autori nazivaju dobom masovnih migracija (Castels i Miller, 1993; Massey i Taylor, 2004). 
stanovništva u državama destinacije, samih migranata, ali i nemigratornog stanovništva u zemlji porekla usled opstanka čvrstih veza sa iseljenicima (Epstein i Gang, 2010: 7-8). Dakle, pored procesa globalizacije, migracije koje su u drugoj polovini prošlog veka postale masovne, u velikoj meri su doprinele stvaranju globalne kulture. ${ }^{3}$

Sam kraj prošlog veka pored toga što predstavlja početak postepenog priključenja istočno-evropskih država u Evropsku uniju, kao i početak procesa njihovog uključivanja u sistem svetskog kapitalizma, predstavlja i period raspada Socijalističke Federativne Republike Jugoslavije (SFRJ), čiji tužni epilog nalazimo u krvavim ratovima na teritoriji bivših članica i kolonama izbeglih i proteranih lica koja su se uglavnom kretala ka svojim matičnim državama. ${ }^{4}$ Pored toga što beleži veliki broj izbeglog stanovništva uglavnom iz Hrvatske i Bosne i Hercegovine, centralni deo Republike Srbije karakteriše i naseljavanje interno raseljenih lica sa Kosova i Metohije, čiji je dolazak posledica ratnih sukoba i bombardovanja, kao i proterivanja od strane albanskog stanovništva. Pored toga što su ovi doseljenici sa sobom doneli ono što su uspeli tokom rata da sačuvaju, i što je bilo moguće poneti, oni prenose i nematerijalnu kulturu zajednice u kojoj su živeli, koja se u dodiru sa kulturom mesta u koje se doseljavaju menja, ali i utiče na modifikaciju kulture domicilnog stanovništva.

Iz perspektive razvoja i oblikovanja domaće, lokalne kulture veoma bitna činjenica jeste da Srbija beleži i veliki broj doseljenika iz istočnih azijskih zemalja. Prvo, reč je o kineskim doseljenicima koji se u značajnom broju naseljavaju širom Evrope (pa i u Srbiju ${ }^{5}$ ), baveći se prvenstveno trgovinom, pri tome uglavnom posedujući radnu vizu i ne zahtevajući državljanstvo. Drugo, poslednjih godina u Srbiji se enormno povećava broj tražilaca azilne zaštite među tranzitnim, interkontinentalnim imigrantima, pretežno iz

Globalna kultura ne podrazumeva „,utapanje“ kultura pojedinačnih naroda, niti dominaciju zapadne kulture u procesu globalizacije, već da se nacionalne kulture i identiteti pod uticajem kompleksnih socioekonomskih i političkih globalnih kretanja, nalaze u procesu redefinisanja (Станојевић, 2014).

4 Bogatije i radno sposobnije stanovništvo, prema podacima UNHCR (2004) uglavnom se nastanjivalo na teritorijama bogatijih država, prvenstveno zemalja Skandinavije (najviše Švedska i Norveška), Nemačke, Kanade i SAD, dok se siromašno i starije stanovništvo kretalo ka državama koje su smatrali svojim matičnim državama, odnosno državama etničkog porekla, koje su bile u sastavu SFRJ. Ovakav pravac kretanja izbeglog stanovništva uticao je negativno na demografsku sliku balkanskih država (Nikitović, 2011).

5 Nema preciznih podataka o njihovom broju i okvirni podaci se drastično razilaze zavisno od izvora. Prema podacima nekadašnjeg Ministarstva međunarodnih odnosa iz 2009., bilo ih je oko 6000 (prema Korać, 2013: 247), dok Unija poslodavaca Srbije procenjuje njihov broj na oko 20.000, a broj trgovinskih radnji na oko 10.000 . 
Sirije, Eritreje, Somalije, Afganistana, Alžira, itd. (Bobić, 2013a: 100). Njihov masovni dolazak (prema podacima MUP-a čak 4000 u 2013. godini) i naseljavanje $u$ jedina dva centra za njihov smeštaj (Banja Koviljača i Bogovađa) izazvao je uznemirenje građana iz ovih sredina i stvaranje otvorenog neprijateljstva prema ovim „nepoželjnim strancima” (Bobić, 2013b). Usled vidne izolovanosti ove grupe imigranata u Srbiji, kada govorimo o njima i njihovom odnosu sa domicilnim stanovništvom, pre možemo analizirati uticaj i opstanak etnonacionalnih predrasuda nego međusobnu interakciju kultura imigranata i domaćina.

Na kraju, u okviru analize kontekstualnog okvira, vredno je napomenuti i uticaj svetske ekonomske krize koja je počela 2008. godine. Iz perspektive teme ovog rada, ona je značajna iz dva razloga: prvo, veliki broj naših emigranata se vraća u Srbiju usled pada životnog standarda, gubitka posla i slabijih izgleda za napredovanje u zemljama destinacije nego što je to bilo ranije. U pogledu kulture lokalne sredine u koju se vraćaju, povratnici vrše značajan uticaj - kao što su stečenim vrednostima i navikama življenja koje su sa sobom poneli u zemlju destinacije uticali na tamošnju kulturu i svakodnevni život, tako i sada sa sobom donose nova kulturna obeležja stečena $\mathrm{u}$ inostranstvu koja kroz interakciju sa lokalnim stanovništvom ugrađuju u ovdašnju kulturu. Drugo, svetska ekonomska kriza koja se i u Srbiji dosta osetila i pogoršala još odavno loš materijalni standard, uticala je i na to da građani kao prioritet postavljaju pad životnog standarda i ekonomske probleme, a tek neznatno primećuju uticaj doseljenika i povratnika na kulturu i vrednosni sistem zajednice.

\section{METOD, KONCEPTUALNI I HIPOTETIČKI OKVIR ISTRAŽIVANJA}

Kao što je u uvodu rečeno, prilikom analize stavova građana prema uticaju migranata na lokalnu kulturu, korišćeni su podaci terenskog istraživanja koje je Institut za sociološka istraživanja Filozofskog fakulteta u Beogradu anketnom metodom prikupio sredinom 2013. godine u okviru šireg projekta „Karakteristike teritorijalnog kapitala u Srbiji“. Istraživanje je sprovedeno na radno sposobnom stanovništvu u dobi od 18 do 65 godina starosti. Pri tome, primenjen je metod studija slučaja u četiri grada srednje veličine, a cilj je bio da se utvrde potencijali razvoja gradova srednje veličine u Republici. U istraživanju je učestvovalo ukupno 1325 ispitanika (tabela 1). Od 376 ispitanika iz Kragujevca, njih 65,6\% oduvek živelo u ovom gradu, dok se $32,0 \%$ se doselilo u nekom periodu svog života. Iz Novog Pazara je 
učestvovalo ukupno 286 ispitanika, od toga 66,5\% starosedelaca, a 30,7\% došljaka. Učešće u istraživanju je uzelo ukupno 321 stanovnika Užica, pri čemu njih $65,7 \%$ oduvek živi u ovom gradu, a njih $31,2 \%$ se ovde doselilo u nekom periodu svog života. Na kraju, ukupno 342 stanovnika Šapca uzelo je učešće u istraživanju, od toga je $62,5 \%$ starosedelaca, dok se u ovaj grad doselilo 37,5\% ispitanika.

Tabela 1. Struktura uzorka

Table 1. Sample structure

\begin{tabular}{|c|c|c|c|c|c|c|c|}
\hline \multirow{2}{*}{ Grad } & \multicolumn{2}{|c|}{ Domaćini } & \multicolumn{2}{|c|}{ Doseljenici } & \multicolumn{2}{|c|}{ Bez odgovora } & \multirow{2}{*}{$\begin{array}{l}\text { Ukupno } \\
\text { (N) }\end{array}$} \\
\hline & $N$ & $\%$ & $N$ & $\%$ & $N$ & $\%$ & \\
\hline Kragujevac & 247 & 65,6 & 120 & 32,0 & 9 & 2,4 & 376 \\
\hline Novi Pazar & 196 & 66,5 & 90 & 30,7 & 8 & 2,8 & 286 \\
\hline Užice & 211 & 65,7 & 100 & 31,2 & 10 & 3,1 & 321 \\
\hline Šabac & 214 & 62,5 & 128 & 37,5 & 0 & 0 & 342 \\
\hline
\end{tabular}

Svaki od navedenih gradova nalazi se u Centralnoj Srbiji, a po razvijenosti na nivou cele države, pozicionirani su na sredini lestvice (Опитине и региони у Републиции Србији, 2014). Prema Profilima zajednice (preuzeto sa zvaničnih sajtova opština ${ }^{6}$ ) sva četiri grada karakteriše industrijska proizvodnja kao i, uz izuzetak Šapca, postojanje državnih i privatnih fakulteta. U prvim decenijama nakon Drugog svetskog rata u njima je proizvodnja kontinuirano rasla, sve do kraja osamdesetih godina prošlog veka, kada privreda beleži pad u čitavoj zemlji. Posledica ubrzanog privrednog razvoja jeste znatan priliv stanovništva u ove opštine, najviše iz naselja iste opštine odnosno okruženja, ali i ostatka Srbije, dok je nešto manji broj stizao iz republika SFRJ i inostranstva. ${ }^{7}$ I nakon urušavanja socijalističkog sistema i produbljavanja sveopšte krize u Srbiji, nastavlja se doseljavanje stanovni-

6 Grad Kragujevac, profil grada, http://www.kragujevac.rs/userfiles/files/Ler/Profil\%20zajednice.pdf; grad Novi Pazar, profil grada, http://www.novipazar.rs/privreda/industrija. asp; grad Užice, profil grada, http://www.graduzice.org/userfiles/files/Community\%20 profile\%20City\%20of\%20Uzice,\%20March\%202010.pdf; grad Šabac, profil grada, http:// www.sabac.org/dokumenta/Sabac\%20profil\%20zajednice.pdf.

7 Podaci koji slede navedeni su prema izdanjima Republičkog zavoda za statistiku koja sadrže rezultate prikupljenih podataka prilikom popisa stanovništva 2011. godine: Пonuc становништва, домаћинстава и станова 2011. у Републицุи Србији, Миграције (2013). Београд: Републички завод за статистику; Попис становниитва, домаћинстава и станова 2011. у Републици Србији, Становништво, упоредни преглед броја становника 1948., 1953., 1961., 1971., 1981., 1991., 2002. и 2011. (2013). Београд: Републички завод за статистику. 
ka na ove teritorije, najviše iz korpusa izbeglih i raseljenih, odnosno ratom ugroženih lica. Tako, prema popisu stanovništva iz 1981., do tada se u Novi Pazar doselilo 8006 stanovnika, a rezultati popisa stanovništva iz 2011. ukazuju da na ovoj opštini živi ukupno 27.666 doseljenika (od ukupno 109.327 stanovnika). Doseljavanje se odvijalo postepeno, a najveći broj doseljenih lica na teritoriju Novog Pazara, beleži se u periodu 1996. - 2000. godine, 3079, što se objašnjava ratom na Kosovu i Metohiji, kada većina gradova teritorijalno bližih ovoj pokrajini beleži porast doseljenog stanovništva. Slično je i sa drugim gradovima: prema popisu stanovništva iz 1981., 41.664 stanovnika Kragujevca je navelo da nije rođeno u ovom gradu. Doseljavanje se nastavlja i svoj vrhunac dostiže nakon doseljavanja Srba sa Kosova i Metohije, tj. u periodu između 1996. i 2000., 9823, da bi danas, tj. prema poslednjem popisu iz 2011. broj doseljenika, nezavisno od toga u kom period su se doselili, dostigao 79.235, od ukupno 177.468 stanovnika, koliko ih je registrovano sa stalnim boravištem na teritoriji ovog grada. Za razliku od njih, preostala dva grada, Šabac i Užice, kao pogranični gradovi najbliži Bosni i Hercegovini u kojoj se na početku devedesetih vodio rat, beleže najveći priliv stanovništva u tom periodu, dakle od 1991. do 1995. godine - Šabac 6037, a Užice 2356. U periodu do 1980., Šabac beleži 23.665, a Užice 17.508 doseljenika. Danas Užice ima ukupan broj od 32.266 doseljenika (od ukupno 78.018 stanovnika), a Šabac 52.991 (od ukupno 115.347 stanovnika).

Propadanje privrede i delimično neuspela privatizacija (osim delimično u Kragujevcu) su onemogućili značajno poboljšanje životnog standarda i nakon ubrzane odblokirane postsocijalističke transformacije nakon 2000. godine. U takvim okolnostima izbeglo i proterano stanovništvo je često posmatrano na negativan način, kao dodatan teret za i ionako „praznu državnu kasu“", uz oživljavanje predrasuda i odbacivanje svega novog što je sa njima pristiglo. Domaće stanovništvo retko uviđa da izbeglice i interno raseljena lica nose dvostruki teret vremena i društva u kojem žive: $s$ jedne strane, isto kao i oni plaćaju cenu društvene tranzicije, a sa druge cenu svog položaja koji je posledica prisilnog napuštanja doma (Bobić, 2008: 102). Ipak, neosporno je da se njihovim dolaskom mnogo toga promenilo, počevši od govora, običaja, vrednosnog sistema, ali i načina ekonomske proizvodnje i međusobne interakcije. Ova činjenica nalaže da se prilikom analize uticaja migranata na lokalnu kulturu koriste funkcionalistički modeli razvijeni u sociološkoj teoriji tokom XX veka, prema kojima se useljenici i njihovi domaćini vremenom prilagođavaju kroz proces akulturacije (Kimlika, 2004). Nastanjujući se na određenoj teritoriji i usled neophodnosti njihove direkthe interakcije sa domicilnim stanovništvom, doseljenici utiču na razvoj i 
oblikovanje lokalne kulture. Pri tome se pod ovim pojmom misli na kulturu koja je „ukorenjena, lokal(izova)na, konkretna, oblikovana i razvijena na nekoj jasno određenoj, specifičnoj teritoriji“" (Geiger Zeman i Zeman, 2010: 114). Pored toga što je „,sačinjena od 'stalnih elemenata' (materijalnog nasleđa i institucija), lokalnu kulturu čine i elementi koji su konstantno u procesu transformacije, a koji čine grad živopisnim i aktivnim organizmom" (Dragićević-Šešić, 2009: 22). Ovi promenljivi elementi koji se nalaze u neprekidnom procesu razvoja odnose se na svakodnevni život stanovništva, običaje, verovanja i sistem vrednosti. Upravo u ovom segmentu lokalne kulture prepoznaje se najjači uticaj imigranata.

Prihvatajući funkcionalistički model, a uz osvrt na društvene prilike u Srbiji, tj. u ispitivanim gradovima, opšta hipoteza rada formulisana je na sledeći način: građani prepoznaju uticaj doseljenika na lokalnu kulturu, ali ipak u većoj meri ističu njihov uticaj na pogoršanje ekonomskog života zajednice, što se može objasniti nezavidnim životnim standardom građana Srbije. Ova hipoteza se odnosi na stav ispitanika i prema doseljenicima sa teritorije bivše SFRJ i prema Kinezima.

Imajući u vidu veliku kulturnu udaljenost kineskih doseljenika kao i isključivo radni karakter njihovog doseljavanja na teritoriju Srbije, i u upitni$\mathrm{ku}$ i u analizi su odvojena pitanja koja se odnose na njih i na doseljenike sa Kosova i Metohije, Hrvatske i Bosne i Hercegovine. Dve posebne hipoteze od kojih se u radu polazi, odnose se na ove dve grupe doseljenog stanovništva.

Prva posebna hipoteza odnosi se na način vrednovanja uticaja doseljenika sa Kosova i Metohije i iz susednih država. Povod za postavljanje ove hipoteze dalo je, s jedne strane, to što su $u$ istraživanju učestvovali i doseljenici na osnovu toga što imaju mesto stalnog boravka na teritoriji grada gde je istraživanje sprovedeno. Drugo, usled činjenice da proces migracija, između ostalog, sučeljava ljude različite ideološke, verske, etničke ili nacionalne pripadnosti i identiteta, jednovremeno ih spajajući i razdvajajući, prihvaćeno je da je on veoma pogodan za ispoljavanje bilo negativnih (prema tuđoj grupi „drugih" i „drugačijih“) ili pozitivnih (prema vlastitoj grupi „naših" i „istih“) predrasuda i stereotipa (Rot, 1989: 381-407). Tako, prvom posebnom hipotezom se tvrdi da će ispitanici koji su i sami došljaci imati pozitioniji stav u odnosu na starosedeoce, kao $i$ da će u manjoj meri uvidati negativan uticaj doseljenika na lokalnu ekonomiju i kulturu, nego što će to činiti druga grupa ispitanika (koja nije migrirala). Ovom hipotezom, obrnuto, tvrdimo da se veći otklon prema došljacima može primetiti kod sedelačkog stanovništva, a što bi bila posledica negationih predrasuda prema "drugom". 
Druga posebna hipoteza se odnosi na stavove ispitanika prema uticaju Kineza koji žive i rade na teritoriji njihovog grada. S obzirom da je reč o kulturno i geografski veoma udaljenom narodu i s obzirom na socijalnu izolaciju odnosno zatvorenost kao karakterističnu crtu načina života Kineza u Srbiji (Korać, 2013), te s obzirom da je prvenstveno reč o ekonomskim ili radnim migracijama, pretpostavlja se da će ispitanici više navoditi njihov uticaj na lokalnu ekonomiju, dok će znatno manje uočavati njihov uticaj na lokalnu kulturu, na natalitet ili neki drugi aspekt društvenog života.

Sam upitnik je bio usmeren na istraživanje teritorijalnog kapitala u Srbiji, dakle, nije bio neposredno kreiran u svrhe ispitivanja teme ovog rada - stavova građana prema doseljenicima, što jeste prepreka detaljnijem i preciznijem istraživanju ovog fenomena. Međutim, on je sadržao pitanja na osnovu kojih se može, makar približno, prosuđivati kako lokalna zajednica (koju čine i starosedeoci i doseljenici) percipira efekte useljavanja na svakodnevni život. Takođe, dobijena empirijska evidencija omogućila je i da se postave odgovarajući rangovi u vezi sa stavovima domicilnog stanovništva prema promenama koje imigranti vrše u lokalnoj zajednici. Kako su u ovom istraživanju učestvovali i sami doseljenici (izbeglice i interno raseljena lica), prikupljeni podaci omogućavaju i uporednu analizu njihovih stavova u odnosu na stavove domicilnog stanovništva, što omogućava testiranje prve posebne hipoteze. Za testiranje druge posebne hipoteze značajno je postojanje posebnih pitanja u upitniku koja se odnose na stavove ispitanika prema uticaju kineskih doseljenika, što će biti prikazano u poslednjem delu ovog rada. Na kraju, treba posebno naglasiti da je istraživanje sprovedeno u obliku studije slučaja gradova, tako da će rezultati svakog od navedenih gradova biti posebno prikazani.

Teorijska osnova pristupa jesu mikroanalitički modeli u čijem je središtu pojedinac koji ocenjuje uticaj migranata na sve aspekte života lokalne zajednice. Njegovi stavovi operacionalizovani su preko ponuđenih iskaza koji su u upitniku predstavljeni skalom Likertovog tipa, pri čemu će za statističku obradu i analizu podataka biti korišćena isključivo deskriptivna analiza. Naravno da ovakav pristup može da naiđe na brojne kritike. Prvenstveno, mikro nivo neosporno uključuje jednu dozu subjektivnosti, tako da se ocena pojedinca ne mora poklapati sa realnim stanjem u pogledu uticaja imigranata i raseljenih lica na kulturni identitet lokalne zajednice. Dalje, primenom kvantitativnog istraživanja na analizu ovog fenomena, gube se značajni podaci za njegovu detaljniju analizu (dodatna pojašnjenja, preciznija određena i sl., što je moguće prikupiti jedino kvalitativnom metodom). $\mathrm{Na}$ kraju, usled nemogućnosti ponavljanja istog istraživanja ostaje otvoreno pi- 
tanje uticaja promenljivih kontekstualnih uslova, konkretno trenutne političke nestabilnosti i lošeg ekonomskog standarda. Realno je pretpostaviti da bi stanovništvo više uviđalo uticaj došljaka na kulturu skretanjem pažnje sa loše ekonomske situacije dodatno otežane dolaskom imigranata. Međutim, s obzirom da su istraživanja ovog tipa kod nas vrlo retka ${ }^{8}$ ostaje stav da je ono, čak i uz moguće pomenute kritike, izuzetno značajno.

\section{STAVOVI ISPITANIKA PREMA UTICAJU DOSELJENIKA SA TERITORIJA DRŽAVA BIVŠE SFRJ NA LOKALNU ZAJEDNICU}

Stavovi ispitanika prema uticaju doseljenog stanovništva na kulturu lokalne sredine, ispitivani su preko sledeća dva iskaza: „Doseljenici remete gradsku kulturu i način života“ $\mathrm{i}$ „Doseljenici doprinose kulturnoj raznolikosti grada".

Tabela 2. Stepen slaganja ispitanika sa stavom: „Doseljenici remete gradsku kulturu i način života" (\%)

Table 2. The degree of respondents' agreement with the attitude: "Immigrants disrupt culture of the city and its way of life" (\%)

\begin{tabular}{llccc}
\hline Grad & & Slaže se & Ne slaže se & Neodlučni \\
\hline \multirow{2}{*}{ Kragujevac } & Domaćini & 32,4 & 38,6 & 27,0 \\
\cline { 2 - 5 } & Doseljenici & 18,6 & 55,0 & 26,4 \\
\hline \multirow{2}{*}{ Šabac } & Domaćini & 24,0 & 54,2 & 21,8 \\
\cline { 2 - 5 } & Doseljenici & 15,6 & 62,5 & 21,9 \\
\hline \multirow{2}{*}{ Užice } & Domaćini & 19,0 & 64,0 & 17,0 \\
\hline \multirow{2}{*}{ Novi Pazar } & Doseljenici & 17,8 & 64,3 & 17,9 \\
\cline { 2 - 5 } & Domaćini & 43,0 & 35,4 & 21,6 \\
\cline { 2 - 5 } & Doseljenici & 25,5 & 50,0 & 24,5 \\
\hline
\end{tabular}

Istraživanja migracija i njihovog višestrukog uticaja na društvo nisu preterano zastupljena u srpskim naučnim krugovima. Malobrojna istraživanja koja su u Srbiji rađena, uglavnom su se ticala uticaja dijaspore na ekonomski razvoj Srbije (Pavlov, Kozma i Velev, 2012; Pavlov i Predojević-Despić, 2013), razvoj nauke i tehnologije u Srbiji (Гречић, 2010; Filipović, 2012), zatim migracionog potencijala građana Srbije (Pavlov, 2009; Vesković Anđelković, 2014) i veoma značajnih demografskih projekcija zasnovanih na migratornim tokovima (Nikitović, 2011; Kupiszewski, Kupiszewska i Nikitović, 2012). Kada je reč o istraživanju prisilnih migracija, ona su uglavnom bila usmerena na izbeglice i interno raseljena lica (Трипковић, 2005; Đorđević-Crnobrnja, 2014), a ne na domicilno stanovništvo. 
Tabela 3. Stepen slaganja ispitanika sa stavom: „Doseljenici doprinose kulturnoj raznolikosti grada" (\%)

Table 3. The degree of respondents' agreement with the attitude:

"Immigrants contribute to the cultural diversity of the town" (\%)

\begin{tabular}{llccc}
\hline Grad & & Slaže se & Ne slaže se & Neodlučni \\
\hline \multirow{2}{*}{ Kragujevac } & Domaćini & 31,7 & 27,7 & 40,4 \\
\cline { 2 - 5 } & Doseljenici & 40,8 & 16,7 & 42,5 \\
\hline \multirow{2}{*}{ Šabac } & Domaćini & 34,4 & 24,6 & 41,0 \\
\cline { 2 - 5 } & Doseljenici & 36,0 & 34,4 & 29,6 \\
\hline \multirow{2}{*}{ Užice } & Domaćini & 35,5 & 36,1 & 28,4 \\
\hline \multirow{2}{*}{ Novi Pazar } & Doseljenici & 38,8 & 28,5 & 32,7 \\
\cline { 2 - 5 } & Domaćini & 37,0 & 38,0 & 25,0 \\
\cline { 2 - 5 } & Doseljenici & 45,6 & 24,4 & 30,0 \\
\hline
\end{tabular}

Rezultati istraživanja prikazani $u$ obe tabele ukazuju na činjenicu da značajan broj ispitanika prepoznaje kulturni uticaj doseljenog stanovništva. Upoređivanjem podataka koji prikazuju stavove o negativnom (tabela 2) i pozitivnom uticaju (tabela 3), primećuje se da ispitanici koji su se i sami doselili na teritoriju određenog grada imaju pozitivniji stav o uticaju grupe kojoj pripadaju, nego što o njima imaju ispitanici koji žive u datom gradu od rođenja, čime se potvrđuje prva posebna hipoteza. Rezultati odslikavaju savremenu društvenu teoriju koja naglašava uzajamno jačanje identiteta i čvrste međusobne povezanosti svetske populacije, iskazanih preko odnosa procesa globalizacije i, uslovno rečeno, nacionalnih država. Prema rečima Glik Šiler, „,doba globalizacije koje karakteriše čvrsta povezanost ekonomije, ljudi i ideja, obeleženo je i jačanjem politike identiteta i slavljenjem nacije ili etničke grupe" (Glick Schiller, Basch i Szanton Blanc 1995: 52). Život u vremenu očigledne borbe i dopune opšteg (globalizacije) i posebnog principa (identiteta nacije ili etničke grupe) koji jedno bez drugog ne bi opstali, uticale su i na oblikovanje teorija o postmodernom društvu koje dovode do usijanja diskusije o pitanjima različitosti i priznavanja različitosti, „,koja se i u ideologiji i u teoriji ponekad uzdiže do kulta" (Трипковић, 2005: 36). Insistiranje na identitetu pretvara se u slavljenje diferencijaliteta i sveopšteg odvajanja. Sučeljavanje posebnosti najviše dolazi do izražaja u migratornim procesima u kojima se bude predrasude o pozitivnosti grupe kojoj pojedinci pripadaju i negativnim karakteristikama onih „drugih“. Tako, u okviru 
realizovanog uzorka doseljeni ispitanici smatraju da su doprineli atraktivnosti i živosti lokalne kulture, dok domaćini na njihov uticaj gledaju kao na urušavanje identiteta i posebnosti koje su nekad imali.

Međutim, da ovaj princip nema apsolutno važenje pokazuje, podatak o značajnom broju ispitanika domaćina koji su se složili sa stavom da je doseljeno stanovništvo doprinelo kulturnoj raznolikosti grada, što „obogaćuje duh lokalne sredine i čini je privlačnijom za druge“ (Geiger Zeman i Zeman, 2010: 114). Takođe, uviđa se značajan udeo doseljenika koji su se složili sa stavom o negativnom uticaju grupe kojoj pripadaju na zatečenu lokalnu kulturu. Ovaj podatak se objašnjava raznolikošću grupe doseljenika s obzirom na poreklo i vreme dolaska u određenu sredinu. Ne pripadaju svi grupi izbeglog i proteranog stanovništva, većina je u jednom periodu svog života, neki i pre raspada SFRJ, došla iz okolnog seoskog područja, tako da i ne smatra da pripada doseljenoj grupi, već domicilnom stanovništvu. Ova grupa "doseljenicima“ smatra osobe koje su u skorije vreme došle ili iz inostranstva ili nekog drugog dela Srbije, a kako su oni malobrojni, doseljenicima najviše smatraju pojedince koji su došli sa nekada ratom zahvaćenih područja. Ovakva perspektiva posmatranja pripadnosti grupi doseljenika je uticala na njihov stav o kulturnom uticaju na lokalnu sredinu.

Uvidom $\mathrm{u}$ podatake $\mathrm{u}$ tabeli 2 primećuje se da se najmanje ispitanika $\mathrm{u}$ Šapcu i Užicu složilo sa tvrdnjom da doseljenici remete gradsku kulturu i način života i da se u ova dva grada beleže najmanja razilaženja stavova pripadnika iz grupa domaćeg i doseljenog stanovništva. Objašnjenje se nalazi prvo, u manjem broju doseljenog stanovništva u ove gradove nego što je to slučaj sa Kragujevcem i Novim Pazarom, što se vidi iz gore prikazanih podataka. Drugo, većina doseljenog stanovništva na teritoriji Šapca i Užica, pored toga što vuče poreklo iz nekog od okolnih sela, potiče iz Hrvatske i Bosne i Hercegovine, dok je na teritoriji Kragujevca i Novog Pazara, pored doseljenika iz okolnih seoskih područja, većina stigla sa teritorije Kosova i Metohije. Sudeći prema rezultatima istraživanju stavova građana prema izbeglim, interno raseljenim licima i azilantima koje je Komeserijat za izbeglice i migracije obavio 2012. godine, domicilno stanovništvo pokazuje veću socijalnu distancu prema licima proteranim sa Kosova i Metohije, nego prema izbeglicama iz Hrvatske i Bosne i Hercegovine (Stavovi građana prema izbeglicama,..., 2012: 51-52). Socijalna distanca je učinila i da domaćini negativnije posmatraju kulturni uticaj interno raseljenih lica nego izbeglica, tj. u ovom slučaju, da Kragujevčani i Novopazarci negativnije posmatraju uticaj doseljenika na lokalnu kulturu, nego što to čine Užičani i Šapčani, što se može objasniti i nižim socijalnim, ekonomskim i kulturnim kapitalom 
imigranata sa Kosova i Metohije. ${ }^{9}$ Takođe, veći stepen socijalne prihvaćenosti utiče i na opadanje međusobne distance ovih grupa što objašnjava i bliskost njihovih stavova, ali i manji stepen opažanja uticaja doseljenog stanovništva.

Prikupljeni podaci ukazuju i na činjenicu da značajan broj građana ne uviđa nikakav uticaj doseljenika na lokalnu kulturu, da je prema ovom fenomenu potpuno ravnodušan i to bilo da je reč o pozitivnom ili negativnom uticaju. Prema pretpostavci iznetoj u okviru opšte hipoteze očekuje se da će podaci ukazati na jasniji stav ispitanika o uticaju doseljenog stanovništva na ekonomski život zajednice. Njihovi stavovi su ispitivani preko sledećih iskaza: „Doseljenici donose nova znanja i veštine i time podstiču razvoj", „Doseljenici povećavaju nezaposlenost“, „Doseljenici povećavaju cene stanova“, „Doseljenici podstiču neformalnu ekonomiju“. Jedino prvi stav ima pozitivnu konotaciju prema uticaju doseljenika na domaću ekonomiju (tabela 4$)$.

Tabela 4. Stepen slaganja ispitanika sa stavom: „Doseljenici donose nova znanja i veštine i time podstiču razvoj" (\%)

Table 4. The degree of respondents' agreement with the attitude: "Immigrants bring new knowledge and skills and thus encourage development" (\%)

\begin{tabular}{llccc}
\hline Grad & & Slaže se & Ne slaže se & Neodlučni \\
\hline \multirow{2}{*}{ Kragujevac } & Domaćini & 22,9 & 33,6 & 43,5 \\
\cline { 2 - 5 } & Doseljenici & 35,0 & 20,0 & 45,0 \\
\hline \multirow{2}{*}{ Šabac } & Domaćini & 26,4 & 38,2 & 35,4 \\
\cline { 2 - 5 } & Doseljenici & 27,1 & 45,0 & 27,9 \\
\hline \multirow{2}{*}{ Užice } & Domaćini & 26,3 & 43,5 & 30,2 \\
\cline { 2 - 5 } & Doseljenici & 20,3 & 33,7 & 46,0 \\
\multirow{2}{*}{ Novi Pazar } & Domaćini & 23,4 & 46,6 & 30,0 \\
\cline { 2 - 5 } & Doseljenici & 29,0 & 31,0 & 40,0 \\
\hline
\end{tabular}

Ostali stavovi izražavaju negativan uticaj na neki od aspekata ekonomije grada, ali kako to nije primarna tema ovog rada, rezultati za svaki od njih

9 Doseljenici sa Kosova i Metohije su komparativno stariji, manje obrazovani, sa većim brojem izdržavanih (dece i starih), i visokim učešćem bolesnih, osoba sa invaliditetom, i sl. Takođe, treba imati na umu da se Srbija više od dve decenije suočavala sa izbegličkim krizama, koje su sporo rešavane, pa je vreme prispeća novih kontingenata proteranih verovatno obrnuto povezano sa stepenom socijalne tolerancije sredine (Bobić, 2005). 
neće ni biti prikazani. Tabelarno su prikazani samo rezultati za stav „Doseljenici povećavaju nezaposlenost" (tabela 5) i to iz razloga što oko polovine ispitanika (u Novom Pazaru više od dve trećine) iz sva četiri grada navodi nezaposlenost kao gorući problem njihove lokalne zajednice, i to u: Kragujevcu 51,6\%, Šapcu 54,1\%, Užicu 46,5\%, Novom Pazaru 70,8\%.

Tabela 5. Stepen slaganja ispitanika sa stavom: „Doseljenici povećavaju nezaposlenost" (\%)

Table 5. The degree of respondents' agreement with the attitude: "Immigrants increase unemployment" (\%)

\begin{tabular}{llccc}
\hline Grad & & Slaže se & Ne slaže se & Neodlučni \\
\hline \multirow{2}{*}{ Kragujevac } & Domaćini & 54,7 & 19,0 & 26,3 \\
\cline { 2 - 5 } & Doseljenici & 45,4 & 22,7 & 31,9 \\
\hline \multirow{2}{*}{ Šabac } & Domaćini & 59,8 & 18,2 & 22,0 \\
\cline { 2 - 5 } & Doseljenici & 56,1 & 24,6 & 9,3 \\
\hline \multirow{2}{*}{ Užice } & Domaćini & 39,0 & 37,2 & 23,8 \\
\cline { 2 - 5 } & Doseljenici & 51,0 & 35,3 & 13,7 \\
\multirow{2}{*}{ Novi Pazar } & Domaćini & 66,0 & 9,7 & 24,3 \\
\cline { 2 - 5 } & Doseljenici & 46,5 & 10,2 & 43,3 \\
\hline
\end{tabular}

Rezultati prikazani u obe tabele (4 i 5) ne idu u potpunosti u prilog osnovnoj opštoj hipotezi. Primećuje se da je stepen neodlučnih ispitanika približan kada su u pitanju stavovi o pozitivnom uticaju doseljenika kako na kulturu, tako i na ekonomiju lokalne sredine. Ono što se izdvaja jeste veliki broj ispitanika koji smatraju da doseljeno stanovništvo negativno utiče na ionako visoku nezaposlenost. Privatizacija koja je počevši od kraja devedesetih godina prošlog veka izvršena pod specifičnim okolnostima i uz velike gubitke (Lazić, 2013) što je rezultiralo propadanjem privrede u ovim industrijskim gradovima doveli su do gašenja velikog broja firmi. To se dalje odrazilo na otpuštanje velikog broja radnika, čime su neretko oni i njihove porodice dovedeni na ivicu egzistencije. S obzirom da se to dešavalo najviše tokom 1990-tih godina, kada je i pristizao najveći broj izbeglica, to su oni, poslužili kao „žrtveni jarac“ građanima koji su u njima potražili krivce za svoj nezavidan položaj. Činjenica je da se njihovim dolaskom povećava konkurencija na tržištu rada, što dodatno stvara odbojnost domaćina prema doseljenicima. 
Čitava ekonomska situacija u zemlji utiče da veliki broj građana i dalje mora prvo da razmišlja o sopstvenoj materijalnoj egzistenciji, pa tek onda o drugim aspektima (su)života. U takvim okolnostima je i realno očekivati da će prvenstveno razmišljati o uticaju doseljenika na ekonomiju i to u negativnom smislu. Kulturni život, njegov razvoj i oblikovanje nisu u fokusu interesovanja još od raspada Jugoslavije pošto od tada srpski narod ulazi u zaista dug period ekonomske stagnacije i nazadovanja, period koji se još uvek nije završio.

Pregledom rezultata istraživanja uviđa se, dakle, da ispitanici prvenstveno ukazuju na uticaj (i to negativan) doseljenika na životni standard lokalne zajednice, što je posledica generalno loših ekonomskih uslova u zemlji. Razmatranje uticaja doseljenog stanovništva na duh zajednice, lokalnu kulturu i tradiciju, tako ostaje u drugom planu, dok inovacije u oblasti materijalne proizvodnje ostaju neprimećene. Ovim je delimično potvrđena opšta hipoteza, imajući u vidu samo ovu grupu doseljenika. Rezultati istraživanja, međutim, potvrđuju i prvu posebnu hipotezu kojom se tvrdi da domaćini kulturni uticaj doseljenika u većoj meri ocenjuju kao negativan, dok ispitanici koji i sami pripadaju grupi doseljenog stanovništva stavljaju akcenat na njihov pozitivan uticaj.

U narednom delu rada biće testirana druga posebna hipoteza koja se odnosi na kulturni uticaj kineskih doseljenika.

\section{STAVOVI GRAĐANA PREMA UTICAJU KINESKIH DOSELJENIKA NA ŽIVOT LOKALNE ZAJEDNICE}

Dolazak Kineza u Srbiju započeo je 1996. godine, u periodu kada sukobi na teritoriji Bosne i Hercegovine i Hrvatske (1991. - 1995.) bivaju okončani, a neposredno pre zaoštravanja odnosa na Kosovu i Metohiji. Opšte siromaštvo, nestabilne vlade, razorene granice srpske države, kako neki teoretičari tvrde (Nyíri, 2003), bili su vrlo privlačni za kineske migrante iz razloga što njihov cilj nije bio da tu ostanu, već su u početku Srbiju posmatrali kao tranzitno područje ka državama Evropske Unije. S druge strane, zanimljivo je da je (o tome su mediji dosta pisali) jedan deo srpskog stanovništva njihov dolazak posmatrao kao politički potez tadašnjeg predsednika Miloševića, u smislu da je on postigao dogovor sa kineskom vladom da pošalje nekoliko hiljada građana koji će dobiti državljanstvo i tako steći pravo izlaska na izbore, na kojima bi ga podržali. Teoretičari su interes Kine tražili isključivo u ideologiji - Miloševićeva Srbija bila je „poslednji bastion komunizma u Evropi“. 
Pokazalo se, međutim, da su ove tvrdnje netačne i da su bile zasnovane na strahu od prolongiranja rušenja Miloševića sa vlasti. Naime, Kinezi nisu tražili, niti danas u značajnom broju traže državljanstvo. Njihov dolazak bio je motivisan povoljnim uslovima za razvoj trgovine i dobrim položajem države za eventualno dalje kretanje ka Zapadu. Pošto su masovno pristizali u ratnom i posleratnom periodu kada je životni standard građana Srbije bio izuzetno loš, a pri tome su se pretežno bavili trgovinom, otvarali radnje sa jeftinom robom (garderoba, igračke, sitnice za kuću, itd.) koja je prosečnom građaninu $\mathrm{u}$ to vreme po ceni bila gotovo nedostupna $\mathrm{u}$ drugim prodavnicama, Kinezi su u Srbiji jako dobro prihvaćeni. I ne samo da je ova roba zahvaljujući njima postala svima dostupna, pa je dolazak kineskih trgovaca utoliko popravio uslove materijalnog standarda građana Srbije, već građani uspevaju da im daju u zakup stanove i lokale koje su posedovali, što će im, zahvaljujući ostvarenim rentama osigurati egzistenciju.

$S$ druge strane, njihov dolazak je imao i negativan uticaj i na građane $i$ na domaću trgovinu. Velika potražnja stanova i lokala uticala je i na rast cena nekretnina, što se negativno odrazilo na obično stanovništvo koje je i samo moralo da izdvaja novac za kupovinu ili iznajmljivanje stanova i lokala. Dalje, privlačeći veliki broj kupaca niskom cenom robe, kineski trgovci su drastično smanjili promet $\mathrm{u}$ domaćim radnjama. To je dalje uticalo na njihovo masovno zatvaranje, pa je značajan broj građana ostajao bez posla. U tom smislu, stanovnici su mogli da osete i negativan uticaj doseljavanja Kineza na njihov standard, uprkos povećanoj dostupnosti robe kao i otvaranju izvesnog broja radnih mesta u njihovim prodavnicama.

Zvaničnog broja kineskih doseljenika nema, ali se spekuliše da ih je na teritoriji Srbije od 6000 do, kako mediji nagađaju, čak i 20.000 (Sekulić i Nedeljković, 2009). Shodno tome, nije poznat ni broj doseljenika kineskog porekla u gradovima koji su ušli u uzorak, premda je većina ispitanika svesna njihovog prisustva. Gotovo svi ispitanici su dali pozitivan odgovor na pitanje „Da li u Vašoj lokalnoj sredini ima kineskih doseljenika?“ - u Šapcu 98,1\%, Užicu 92,2\%, Kragujevcu 90\%, i Novom Pazaru 88\%. Odgovori na pitanje o njihovom uticaju na lokalnu sredinu, ${ }^{10}$ prikazani su na slici 1.

10 Ovo pitanje je bilo otvorenog tipa, što znači da su ispitanici mogli slobodno da iskažu uticaj kineskih doseljenika na njihovu lokalnu sredinu. Prilikom obrade prikupljenih podataka, članovi istraživačkog tima su popisali sve odgovore na ova pitanja, a radi lakoće obrade podataka su ih grupisali prema srodnosti i tako svakom odgovoru (ili grupi odgovora), dodelili šifru koja je kasnije ušla u bazu podataka. S obzirom da je spisak svih odgovora dostupan svim članovima istraživačkog tima, šifriranjem se nije izgubila raznolikost odgovora ispitanika. 
Slika 1. Distribucija odgovora na pitanje „Kakav je uticaj kineskih doseljenika na Vaš grad?" (\%)

Figure 1. The distribution of answers to the question „What is the influence of Chinese immigrants in your city?" (\%)

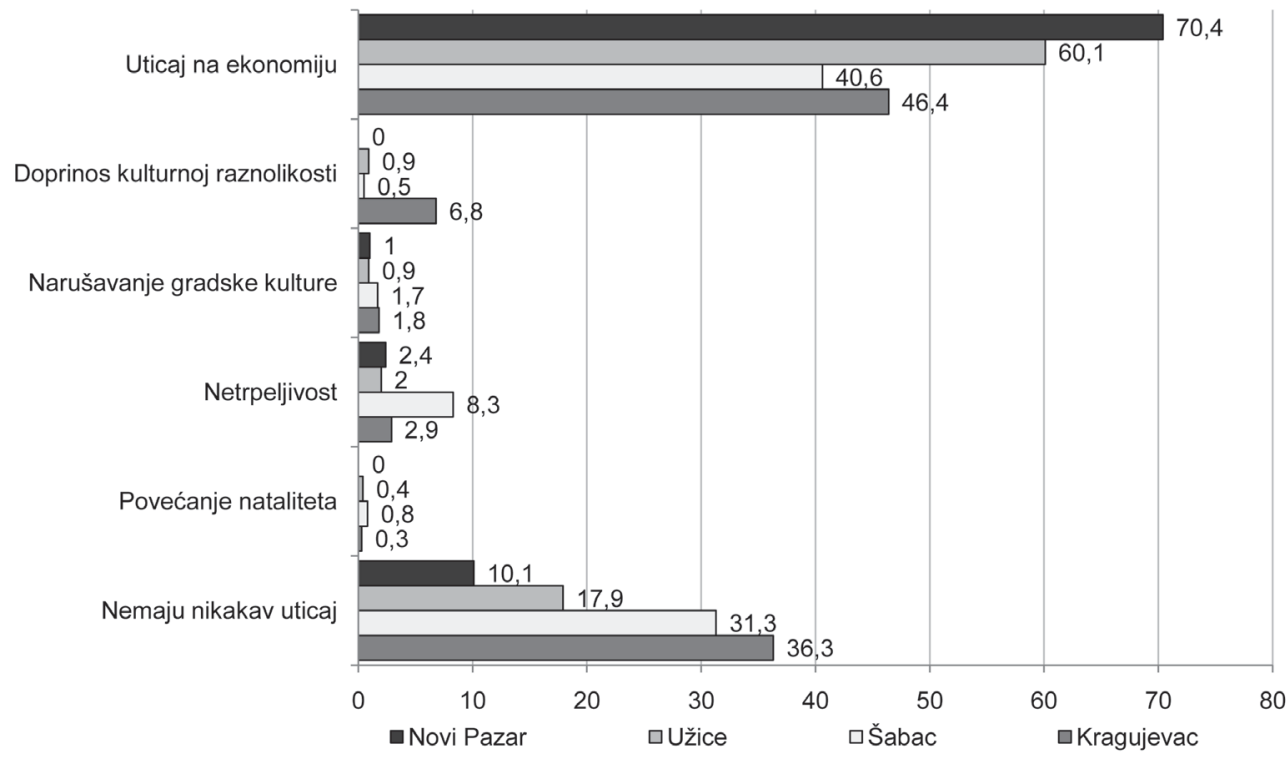

Nema sumnje da građani i dalje na prvom mestu i uz značajnu prednost $\mathrm{u}$ odnosu na druge moguće uticaje, ističu ekonomski uticaj doseljavanja Kineza na njihov grad. Primećuje se da je najviše Novopazaraca istaklo ekonomski uticaj, čak 70,4\% ispitanika iz ovog grada. Daljom analizom prikupljenih podataka uviđa se da je najveći udeo, čak 42,8\% naveo negativan uticaj, u smislu narušavanja domaće industrije i trgovine. Ovaj podatak ne iznenađuje, ako se ima u vidu da je Novi Pazar devedesetih godina prošlog veka pre dolaska Kineza i u prvim godinama nakon toga, bio vodeći grad po proizvodnji garderobe od tekstila i kože. S obzirom da je domaća proizvodnja koja je pokrivala tržište bivše SFRJ propadala u isto vreme kada je došlo i do raspada zajedničke države i ratova, a uvoz robe bio je otežan zbog međunarodnih ekonomskih sankcija, došlo je do neopravdanog skoka cena ovoj robi, dok je narod postajao sve siromašniji. Ipak, postojanje evidentne nekonkurentnosti je novopazarskim industrijalcima koji $\mathrm{u}$ to doba započinju biznis ove vrste omogućilo da osvoje domaće tržište. Nabavlja- 
nje sirovina uglavnom iz Turske ${ }^{11}$ po relativno povoljnim uslovima kao i upošljavanje tamošnje radne snage, takođe pod povoljnim okolnostima (nije bilo tržišta, tekstilna industrija je propala, pa su građani radili uz minimalnu nadoknadu), što je sve omogućavalo da proizvodi budu dostupni velikom delu stanovništva. Međutim, Kinezi donose još jeftiniju robu i tako postepeno uništavaju tekstilnu industriju u ovom gradu koja je danas daleko ispod onoga što je bila krajem prošlog veka.

Ni u jednom drugom gradu nije bilo toliko ispitanika koji su uticaj Kineza na domaću ekonomiju ocenili toliko negativno. Užičani, koji su na drugom mestu po broju ispitanika koji ističu ekonomski uticaj (60,1\%), u mnogo manjoj meri iznose negativan uticaj ovih imigranata -15,6\%. Ako se ima $\mathrm{u}$ vidu da su kineski trgovci samo neznatno svojim proizvodima zamenili proizvode domaće privrede, pošto je u ovom gradu dominantna metalna industrija, onda se ovaj podatak mogao i očekivati. Slično je i sa preostala dva grada. U Šapcu, gradu koji karakteriše hemijska industrija, uglavnom farmaceutska, 40,6\% ispitanika primećuje ekonomski uticaj, pri čemu 9,8\% odgovora ima negativnu konotaciju; dok u Kragujevcu, gradu sa metalnom i mašinskom industrijom 46,4\% ispitanika uviđa ekonomski uticaj, a 11,4\% smatra da je on negativan.

Na osnovu iznetih podataka, može se zaključiti da ispitanici smatraju da kineski trgovci čine dostupnim veliki asortiman proizvoda običnom građaninu, što je objašnjeno dugotrajnom finansijskom krizom. Iako se prema izveštavanju medija smatra da ovi imigranti polako napuštaju Srbiju usled pojačane ekonomske krize koja se odrazila na smanjeni profit, evidentno je da baš zahvaljujući njoj, njihove prodavnice bivaju i dalje pune. Zahvaljujući ovakvoj situaciji, građani Srbije i nemaju drugu asocijaciju kada im se pomenu Kinezi osim njihovih prodavnica i dostupne robe, čiji loš kvalitet ne ostaje nezapažen. U svakom gradu je bilo onih koji su navodili nekvalitet kineskih proizvoda, pri čemu se, očekivano, ističu Novopazarci, gde je ovu ocenu navelo čak $15,6 \%$ ispitivanih građana.

Na osnovu rezultata prikazanih na slici 1. može se zaključiti da, posle ekonomskog uticaja, koji se ističe kao dominantan, građani na drugom

11 Stanovništvo koje se u više etapa iseljavalo iz Novog Pazara, uglavnom je biralo Tursku kao odredište. S obzirom da u ovoj opštini živi većinom muslimansko stanovništvo, uglavnom nastanjeno (ili, još i više, poturčeno) za vreme osmanske vladavine ovim prostorima čini se sasvim prirodno da ova lokalna zajednica ima najbrojniju dijasporu u navedenoj državi. Članovi njihove dijaspore ne pomažu rodbini jedino tako što šalju novac, već su još više usmereni na njihovo umrežavanje sa tamošnjom zajednicom. Ovakav odnos dijaspore i nemigratornog stanovništva bio je motiv i pokretač započinjanja tekstilne proizvodnje u ovom gradu, obezbedivši sirovine po povoljnim uslovima. 
mestu navode indiferentnost prema došljacima. U tom pogledu su Kragujevčani u najvećoj meri (36,6\%) naveli da ne primećuju njihov uticaj, dok se tako najmanje izjasnilo ispitanika iz Novog Pazara, 10,1\%, a razlog je, pretpostavlja se, u zaista primetnom ekonomskom uticaju imigracije. Što se tiče uticaja Kineza na kulturu, bilo u smislu doprinosa raznolikosti domaće kulture ili njenom narušavanju, on ostaje gotovo neprimetan - najviše ga primećuju Kragujevčani 8,6\%, zatim Šapčani 2,2\%, pa ispitanici iz Užica $1,8 \%$, i najmanje iz Novog Pazara 1\%. Zanimljivo je da kulturni uticaj ispitanici najviše prepoznaju u kineskoj hrani koja biva sve više prihvaćena kod domicilnog stanovništva, i jeziku, ali ne u smislu da se srpski jezik menja (što je praktično nemoguće) već da njihov govor doprinosi kulturnoj raznolikosti grada. Jedino ispitanici iz Novog Pazara ne primećuju nikakav pozitivan uticaj ovih imigranata, već smatraju da oni samo narušavaju izgled grada i gradsku kulturu.

Razlog za slabo prepoznavanje kulturnog uticaja Kineza, prvenstveno se nalazi u velikoj kulturnoj distanci ova dva naroda (počevši od jezika, načina življenja i odnosa prema životu), a zatim u načinu svakodnevnog života kineskih trgovaca koji gotovo sve vreme provode $u$ prodavnicama. Komunikacija sa lokalnim stanovništvom se svodi na poslovni odnos prodavca i kupca, ili mnogo ređe poslodavca i prodavca. Zanimljivo je da čak i obroke pripremaju sami (gotovo je nemoguće videti ih u restoranima domaće kuhinje, iako ne važi obrnuto), da decu uglavnom vode sa sobom na posao, da u prodavnicama preko satelita gledaju isključivo programe na kineskom jeziku, a komunikaciju, osim što poslovno moraju da razgovaraju sa domaćim stanovništvom, svode na pripadnike svoje nacije. Čak prema rezultatima nekih istraživanja (Korać, 2013) njihova komunikacija je još više ograničena - svodi se na došljake iz istog mesta porekla ili, preko Skajpa, na nemigratorno stanovništvo u zemlji porekla, njihovu rodbinu i prijatelje. Ovakav način njihovog društvenog života u Srbiji je verovatno i podstakao neke od ispitanika da postave pitanje o tome da li i gde njihova deca idu u školu, gde se leče, a nekoliko ispitanika je postavilo i zanimljivo pitanje o mestu njihovog sahranjivanja. S obzirom da su njihove migracije privremenog karaktera i da je reč o radnim migracijama što implicira da dolaze u godinama kada su uglavnom zdravi, pretpostavlja se da kada se desi nešto neočekivano poput bolesti ili smrti odlaze/bivaju prebačeni u matičnu zemlju. Svakako, ove dileme ispitanika u vezi sa odgovorom na pitanje o uticaju Kineza koje su podstaknute socijalnom izdvojenošću ove grupe svedoče o socijalnoj distanci u odnosu na srpske građane u svakom pogledu i gotovo neprimetnog uticaja na kulturu gradova. 
Uviđanje uticaja ovih doseljenika na ekonomski život zajednice, jedini je, segment društvenog života gradova koji se promenio njihovim dolaskom. Istina, miris kineske hrane iz značajnog broja njihovih restorana privukao je stanovništvo da prihvate ovu vrstu raznolikosti i da rado probaju ukuse pristigle iz Azije, ali nije bio dovoljan da se umeša u lokalnu kulturu. „Puritanski duh" koji ovaj narod naseljen u Srbiji pokazuje i (dobrovoljna) socijalna isključenost, učinili su ih ne samo „kulturno nevidljivim“, već i beznačajnim za svaki vid neekonomskog života lokalne zajednice.

\section{ZAKLJUČAK}

Osnovni cilj rada bilo je prikazivanje stavova građana centralnog dela Srbije o uticaju migranata na njihovu lokalnu kulturu, zasnovano na rezultatima anketnog istraživanja. Doseljenici su podeljeni u dve grupe na osnovu principa kulturne bliskosti - stanovništvo koje potiče iz država bivše Jugoslavije i Kineze. Usled nedostatka podataka, u radu nije razmatran uticaj azilanata i povratnika. Podaci vezani za stav ispitanika prema uticaju doseljenog stanovništva upoređeni su sa njihovim stavom o uticaju ove grupe na ostale segmente društvenog života lokalne zajednice, radi utvrđivanja značaja koji ispitanici pridaju kulturnim promenama njihovog grada.

Nakon iznetih podataka i analiza, može se reći da se delimično potvrđuje opšta hipoteza da, pod uticajem konteksta srpskog društva, naši građani više primećuju ekonomski, nego širi kulturni uticaj doseljenika. Ova opšta hipoteza se najviše potvrdila u pogledu uticaja koji vrše kineski doseljenici, pri čemu ovakav stav naših građana nije usmeravan samo trenutnom situacijom u zemlji, već i načinom života samih Kineza. Njihova odvojenost u odnosu na građane Srbije, učinila je i da ispitanici gotovo uopšte ne primećuju neku drugu vrstu uticaja na lokalnu zajednicu, što pokazuju rezultati istraživanja čije smo podatke koristili u ovom tekstu. Ovakvi rezultati idu u korak sa drugom posebnom hipotezom kojom je i utvrđeno isticanje ekonomskog uticaja kineskih doseljenika na grad.

Opšta hipoteza, međutim, biva delom i opovrgnuta prilikom razmatranja stavova građana o uticaju doseljenika sa Kosova ili susednih država. Rezultati ne pokazuju veći stepen opredeljenosti građana u pogledu stava o pozitivnom uticaju doseljenika na ekonomiju nego što je broj opredeljenih ispitanika u pogledu njihovog uticaja na lokalnu kulturu. Pretpostavlja se da ovakvi rezultati ukazuju na nezainteresovanost građana Srbije za bilo koje promene koje ne ugrožavaju njihovu materijalnu egzistenciju. Ovo se, naravno, objašnjava odsustvom bržeg i stabilnijeg ekonomskog oporavka 
zemlje, te opštom i dugotrajnom pauperizacijom stanovništva. Takav kontekst uzrokovao je da se građani senzibilišu samo kada se postavlja pitanje dodatnog ugrožavanja njihovog materijalnog položaja. Tako, oni postaju najodređeniji kada je u pitanju uticaj doseljenika na nezaposlenost, koju ističu u velikom obimu.

Razlika u posmatranju uticaja doseljenika od strane ispitanika koji pripadaju domaćem stanovništvu grada i od strane ispitanika koji su se i sami doselili u grad, što je tvrđeno u okviru početne posebne hipoteze, takođe se potvrdila $u$ rezultatima. Veliki uticaj predrasuda o superiornosti vlastite grupe i nesavršenosti druge, pokazuje se $\mathrm{u}$ tome što doseljenici uglavnom uviđaju svoj pozitivan uticaj na zatečenu lokalnu kulturu, dok je među domicilnim stanovništvom više onih koji ovaj uticaj ocenjuje kao negativan. Ipak, s obzirom na to da mnogo faktora određuje smer formiranja stavova kod pojedinaca, njihovi stavovi (obe grupe) nisu usaglašeni i oštro razdvojeni s obzirom na poreklo.

Na kraju se može konstatovati da veliki broj neopredeljenih u pogledu kulturnog uticaja doseljenika na lokalnu sredinu i male razlike kod opredeljenja domaćina i doseljenog stanovništva, ukazuju na, šire uzev, relativnu prihvaćenost imigranata. To ne implicira njihovu kulturnu asimilaciju i ne poništava njihov zaseban identitet, već ukazuje na meru tolerancije i otvorenosti za druge i drugačije među lokalnim stanovništvom.

\section{LITERATURA}

Bobić, M. (2005). Migracije, u: I. Milenković (ur.). Studije o izbeglištvu. Beograd: Grupa 484.

Bobić, M. (2008). Forced Migrants in Serbia: Refugees and Internally Displaced Persons - Facts and Figures, Coping Strategies, Future, Refuge, 26 (1): 101-110.

Bobić, M. (2010). Migracije i politike u Srbiji 1991-2010, Pravo i društvo, 1 (2): 103-125.

Bobić, M. (2013a). Postmoderne populacione studije. Beograd: ISI FF - Čigoja štampa.

Bobić, M. (2013b). Imigracija u Srbiji: stanje i perspektive, tolerancija i integracija, Демографија, 10: 99-115.

Bobić M. i Babović, M. (2013). Međunarodne migracije u Srbiji - stanje i politike, Sociologija, 55 (2): 209-228, doi:10.2298/SOC1302209B.

Bonifazi, C. (2004). Evolution of regional patterns of international migration in Europe, International migration in Europe: new trends, new methods of analysis, Rome, November $25-27,2004$.

Castels, S. i Miller, M. J. (1993). The Age of Migration. New York - London: The Guilford Press. 
Dragićević-Šešić, M. (2009). Kultura u funkciji razvoja grada, Kultura, 122/123: 20-40.

Đorđević-Crnobrnja, J. (2014). Migrations from the Gora Region at the End of the 20th and the Beginning of the 21th Century, Гласник Етнграфског института САНУ, 62 (2): 35-47, doi: 10.2298/GEI1402035D.

Epstein, G. S. i Gang, I. N. (2010). Migration und Kultur. Bonn: Forschungsinstitut zur Zukunft der Arbeit.

Filipović, J. (2012). Management of a Diaspora Virtual University as a Complex Organization, Serbian Diaspora Virtual University: An Emerging Leadership of a Nation. Saarbrücken: Lambert Academic Publishing.

Geiger Zeman, M. i Zeman, Z. (2010). Uvod u sociologiju (održivih) zajednica. Zagreb: Institut društvenih znanosti „Ivo Pilar".

Glick Schiller, N., Basch L. i Szanton Blanc, C. (1995). From Immigrant to Transmigrant: Theorizing Transnational Migration, Anthropological Quartely, 68 (1): 48-63.

Гречић, В. (2010). Српска научна дијаспора. Београд: Институт за међународну политику и привреду.

Held, D., McGrew, A., Goldblat, D. i Perraton, J. (1999). Global Transformations. Stanford: Stanford University Press.

[Kymlicka, W.] Kimlika, V. (2004). Multikulturalizam: multikulturno građanstvo. Podgorica: CID.

Korać, M. (2013). Transnational pathways to integration: Chinese traders in Serbia, Sociologija, 55 (2): 245-260, doi:10.2298/SOC1302245K.

Kupiszewski, M., Kupiszewska, D. i Nikitović, V. (2012). Uticaj demografskih i migracionih tokova na Srbiju. Beograd: Međunarodna organizacija za migracije, Misija u Beogradu.

Lazić, M. (2013). Čekajući kapitalizam. Beograd: Službeni glasnik.

Massey, D. S. i Taylor, J. E. (ur.) (2004). International Migration. Prospects and Policies in a Global Market. New York: Oxford University Press.

Nikitović, V. (2011). Može li izbeglička populacija u Srbiji značajno uticati na njenu demografsku budućnost?, u: G. Penev (ur.). Migracije, krize i ratni sukobi na Balkanu s kraja 20. veka. Beograd: Društvo demografa Srbije - DèmoBalk, 215-224.

Nyíri, P. (2003). Chinese Migration to Eastern Europe, Internation Migration, 41 (3): 239265, doi: 10.1111/1468-2435.00248.

Pavlov, T. (2009). Migracioni potencijal Srbije. Beograd: Grupa 484.

Pavlov, T., Kozma, R. i Velev, B. (2012). Dijaspora kao resurs lokalnog razvoja. Beograd: USAID, Srbija - Grupa 484.

Pavlov, T. i Predojević-Despić, J. (2013). Transnacionalno preduzetništvo: iskustva migranata-povratnika u Srbiju, Sociologija, 55 (2): 261-282, doi:10.2298/SOC1302261P.

Rot, N. (1989). Osnovi socijalne psihologije. Beograd: Zavod za udžbenike i nastavna sredstva.

Sekulić N. i Nedeljković, V. (2009). U Srbiji na crno radi 20.000 Kineza!, Press online (16. decembra 2009.), http://www.pressonline.rs/info/politika/92036/u-srbiji-na-crnoradi-20000-kineza.html (20. 01. 2015.).

Станковић, В. (2014). Србија у процесу спољних миграција, Попис становништва, домаћинстава и станова 2011. у Републици Србији. Београд: Републички завод за статистику. 
Станојевић, М. (2014). Изазови глобализације културе: културни идентитет и глобализација, у: У. Шуваковић, В. Вулетић и Ј. Ћирић (ур.). Глобализација и десуверенизација. Београд - Косовска Митровица: Српско социолошко друштво, Институт за упоредно право - Филозофски факултет Универзитета у Приштини са привременим седиштем у Косовској Митровици, 328-345.

Stavovi građana prema izbeglicama, interno raseljenim licima i tražiocima azila (2012). Beograd: Комесаријат за избеглице и миграције, http://www.kirs.gov.rs/docs/ izvestaji/Stav_gradjana_prema_izbeglicama,_IRL_i_traziocima_azila_12_10_2012. pdf (22. 01. 2015.).

Трипковић, Г. (2005). Избеглице - културни и социјални изазов, Социолошки преглед, 39 (1): 33-45.

Vertovec, S. (2004). Trends and Impacts of Migrant Transnationalism. Oxford: University of Oxford, Centre on Migration, Policy and Society (Working Paper No. 3), https:// www.compas.ox.ac.uk/fileadmin/files/Publications/working_papers/WP_2004/ WP0403.pdf (22. 01. 2015.).

Vesković Anđelković, M. (2014). Karakteristike i stavovi potencijalnih prekograničnih migranata iz Centralne Srbije, u: M. Petrović (ur.). Strukturni i delatni potencijal lokalnog razvoja. Beograd: ISI FF - Čigoja štampa, 335-352.

\section{IZVORI}

Општине и региони у Републици Србији (2014). Београд: Репубдички завод за статистику.

Попис становништва, домаћинстава и станова 2011. у Републиции Србији, Становништво, упоредни преглед броја становника 1948., 1953., 1961., 1971., $1981 .$, 1991., 2002. и 2011. (2013). Београд: Републички завод за статистику.

Попис становништва, домаћинстава и станова 2011. у Републиции Србији, Миграцุије (2013). Београд: Републички завод за статистику.

UNHCR (2004). Statistical Yearbook. Trends in Displacement, Protection and Solutions. Geneva. 


\title{
Attitudes of the Citizens of the Central Part of Serbia towards the Influence of Immigrants on Local Culture and Tradition
}

\author{
Milica Vesković Anđelković, Mirjana Bobić
}

\begin{abstract}
SUMMARY
There has been an increasing number of immigrants arriving to Serbia from various places ever since the end of the last century. It is primarily a forced displaced population from war affected territories in the 1990s who have still been living in Serbia even two decades after completion of the conflict and the relative normalization of relations. Furthermore, the number of asylum seekers and irregular migrants has also enormously increased. Since demographic forecasts and experiences of other former socialistic countries show that migration transition towards immigration is to be expected in the coming decades, especially with the formal EU membership, it seems there is a need for greater visibilisation of this phenomenon in order to be adequately prepared to face these challenges. The aim of this paper is to provide an overview of the geopolitical position of Serbia and lay down the long-term prospects regarding immigration as well as to shed light on the attitudes of Serbian citizens towards immigrants, especially when it comes to their influence on the local culture, customs and everyday life. The data presented and analysed were collected by field survey research carried out by the Institute for Sociological Research of the Faculty of Philosophy in Belgrade in 2013. Besides analysing attitudes of the local population concerning the influence of refugees, the authors also examine their opinion on the foreigners' impact on culture and everyday life in local communities.
\end{abstract}

KEY WORDS: Serbia, migration, immigrants, culture, tradition 


\title{
Stavovi građana središnjeg dijela Srbije prema utjecaju doseljenika na tradiciju i kulturu njihove lokalne zajednice
}

\author{
Milica Vesković Anđelković, Mirjana Bobić
}

\begin{abstract}
SAŽETAK
Od kraja prošloga stoljeća do danas u Srbiji se povećava broj imigranata, koji pristižu s više strana. Prije svega je riječ o prisilno raseljenom stanovništvu s područja bivše Jugoslavije, koji su se i više od dva desetljeća nakon završetka sukoba i relativne normalizacije odnosa zadržali na srpskom teritoriju. Značajno je povećan i broj tražitelja azila kao i iregularnih migranata. Budući da demografske projekcije i iskustva bivših socijalističkih zemalja govore da je u sljedećih nekoliko desetljeća realno očekivati migracijsku tranziciju u smjeru imigracije, a posebno s formalnim članstvom $\mathrm{u}$ EU-u, čini se da je potrebno povećati vidljivost tog fenomena radi prilagođavanja tim društvenim promjenama. Cilj je ovoga rada da uz osvrt na geopolitički položaj Srbije i dugoročne prognoze u pogledu imigracije pruži pregled stavova građana Srbije prema doseljenicima, naročito u odnosu na njihov utjecaj na lokalnu kulturu, običaje i svakodnevicu. Izneseni i analizirani podaci prikupljeni su terenskim anketnim istraživanjem koje je Institut za sociološka istraživanja Filozofskog fakulteta u Beogradu proveo 2013. U radu se osim stavova domicilnog stanovništva o utjecaju imigranata analizira i njihovo mišljenje o utjecaju stranaca na kulturu i svakodnevni život u njihovim lokalnim sredinama.
\end{abstract}

KLJUČNE RIJEČI: Srbija, migracija, doseljenici, kultura, tradicija 